\title{
Revegetation pattern affecting accumulation of organic carbon and total nitrogen in reclaimed mine soils
}

\author{
Ping P Zhang ${ }^{1,2,3}$, Yan L Zhang ${ }^{3,4}$, Jun C Jia $^{3,4}$, Yong X Cui ${ }^{3,4}$, Xia Wang $^{3,4}$, Xing C Zhang $^{3,4}$, Yun Q Wang ${ }^{\text {Corresp. 1,2 }}$ \\ ${ }^{1}$ State Key Laboratory of Loess and Quaternary Geology, Institute of Earth Environment, Chinese Academy of Sciences, Xi'an, China \\ 2 CAS Center for Excellence in Quaternary Science and Global Change, Xi'an, China \\ 3 Institute of Soil and Water Conservation, Chinese Academy of Science and Ministry of Water Resources, Yangling, China \\ 4 University of Chinese Academy of Sciences, Beijing, China \\ Corresponding Author: Yun Q Wang \\ Email address: wangyq@ieecas.cn
}

Selecting optimal revegetation patterns, i.e., patterns that are more effective for soil organic carbon (SOC) and total nitrogen (TN) accumulation is particularly important for mine land reclamation. However, there have been few evaluations of the effects of different revegetation patterns on the SOC and TN in reclaimed mine soils on the LoesS Plateau, China. In this study, the SOC and TN stocks were investigated at reclaimed mine sites (RMSs), including artificially revegetated sites (ARSs) (arbors [Ar], bushes [Bu], arborbush mixtures $[A B]$, and grasslands $[G r])$ and a natural recovery site (NRS), as well as at undisturbed native sites (UNSs). Overall, the SOC and TN stocks in the RMSs were lower than those in the UNSs over 10-13 years after reclamation. The SOC stocks in the RMSs and UNSs only differed in the top $0-20 \mathrm{~cm}$ of the soil $(p<0.05)$. Except for those in Ar, the SOC and TN stocks in the ARSs were significantly larger than those in the NRS $(p<0.05)$. Compared with those in the NRS, the total SOC stocks in the $100 \mathrm{~cm}$ soil interval increased by $51.4 \%, 59.9 \%$, and $109.9 \%$ for $\mathrm{Bu}, \mathrm{AB}$, and $\mathrm{Gr}$, respectively, and the TN stocks increased by $33.1 \%, 35.1 \%$, and $57.9 \%$. The SOC stocks in the $0-100 \mathrm{~cm}$ soil interval decreased in the order of $\operatorname{Gr}\left(3.78 \mathrm{~kg} \mathrm{~m}^{-2}\right)>A B\left(2.88 \mathrm{~kg} \mathrm{~m}^{-2}\right) \geq B u\left(2.72 \mathrm{~kg} \mathrm{~m}^{-2}\right)$, and the TN stocks exhibited a similar trend. These results suggest that grasslands were more favorable than woodlands for SOC and TN accumulation in this arid area, especially in Ar. Thus, in terms of the accumulation of SOC and TN, grassland planting is recommended as a revegetation pattern for areas with reclaimed mine soils. 


\section{Revegetation pattern affecting accumulation of organic} 2 carbon and total nitrogen in reclaimed mine soils

5 Pingping Zhang ${ }^{1,2,3}$, Yanle Zhang ${ }^{3,4}$, Junchao $\mathrm{Jia}^{3,4}$, Yongxing Cui ${ }^{3,4}$, Xia Wang ${ }^{3,4}$, Xingchang

6 Zhang ${ }^{3,4}$, Yunqiang Wang ${ }^{1,2 *}$

$8{ }^{1}$ State Key Laboratory of Loess and Quaternary Geology, Institute of Earth Environment,

9 Chinese Academy of Sciences, Xi'an, Shaanxi 710075, China

$10{ }^{2}$ CAS Center for Excellence in Quaternary Science and Global Change, Xi'an, 710061, China

11 Institute of Soil and Water Conservation, Chinese Academy of Science and Ministry of Water

12 Resources, Yangling 712100, China

13 4niversity of Chinese Academy of Sciences, Beijing 100049, China

$14{ }^{*}$ Corresponding author:

15 Yunqiang Wang ${ }^{1,2}$

16 Yanxiang Road, Xi'an, Shaanxi, 71006, China

E-mail address: wangyq@ieecas.cn;wangyunq04@163.com 


\section{Abstract}

Selecting optimal revegetation patterns, i.e., patterns that are more effective for soil organic carbon (SOC) and total nitrogen (TN) accumulation is particularly important for mine land reclamation. However, there have been few evaluations of the effects of different revegetation patterns on the SOC and TN in reclaimed mine soils on the Loess Plateau, China. In this study, the SOC and TN stocks were investigated at reclaimed mine sites (RMSs), including artificially revegetated sites (ARSs) (arbors [Ar], bushes [Bu], arbor-bush mixtures [AB], and grasslands [Gr]) and a natural recovery site (NRS), as well as at undisturbed native sites (UNSs). Overall, the SOC and TN stocks in the RMSs were lower than those in the UNSs over 10-13 years after reclamation. The SOC stocks in the RMSs and UNSs only differed in the top $0-20 \mathrm{~cm}$ of the soil $(p<0.05)$. Except for those in Ar, the SOC and TN stocks in the ARSs were significantly larger than those in the NRS $(p<0.05)$. Compared with those in the NRS, the total SOC stocks in the $100 \mathrm{~cm}$ soil interval increased by $51.4 \%, 59.9 \%$, and $109.9 \%$ for $\mathrm{Bu}, \mathrm{AB}$, and $\mathrm{Gr}$, respectively, and the TN stocks increased by $33.1 \%, 35.1 \%$, and $57.9 \%$. The SOC stocks in the $0-100 \mathrm{~cm}$ soil interval decreased in the order of $\operatorname{Gr}\left(3.78 \mathrm{~kg} \mathrm{~m}^{-2}\right)>\mathrm{AB}\left(2.88 \mathrm{~kg} \mathrm{~m}^{-2}\right) \geq \mathrm{Bu}\left(2.72 \mathrm{~kg} \mathrm{~m}^{-2}\right)$, and the TN stocks exhibited a similar trend. These results suggest that grasslands were more favorable than woodlands for SOC and TN accumulation in this arid area, especially in Ar. Thus, in terms of the accumulation of SOC and TN, grassland planting is recommended as a revegetation pattern for areas with reclaimed mine soils.

\section{Introduction}

With growing global warming, soil organic carbon (SOC) has received increasing attention worldwide. As the largest terrestrial pool of organic carbon, a slight change in SOC pool could significantly alter the atmospheric $\mathrm{CO}_{2}$ concentration and exert great effect on global climate (Lal, 2004). Besides, SOC and total nitrogen (TN) are key indicators of the fertility of quality of soil, and they are highly important for improving soil structure and increasing crop productivity (Jia et al., 2012). Therefore, understanding the SOC and TN concentration and stock in ecosystems is essential for alleviating the global climate change and determining the sustainable management of land resources (Zhang et al., 2018).

The adverse effects of land degradation on SOC and TN cycles have received considerable scientific attention worldwide in recent decades. Coal mining, especially surface mining, can considerably alter habitat and cause land degradation (Mukhopadhyay and Masto, 2016; Liu et al., 2017). Mining eliminates vegetation, disrupts soil profiles, and changes topography and geological permanently (Bao et al., 2017; Ahirwal and Maiti, 2018). These processes further enhance soil erosion phenomena, interrupt the natural carbon $(\mathrm{C})$ and nitogen $(\mathrm{N})$ cycles, and reduce the soil organic carbon (SOC) and total nitrogen (TN) pools (Shrestha and Lal, 2010). However, appropriate reclamation approaches and management practices can reduce the soil degradation and increase the accumulation of SOC and TN (Ahirwal et al., 2017a,b).

Unlike naturally formed soils, reclaimed mine soils are pedogenically young soils, which are 
56 highly disturbed and artificially constructed from the materials excavated during mining

57 (Shrestha and Lal, 2008; Cao et al., 2015). They are often characterized by poor chemical, 58 physical, and biological properties, such as low nutrient levels, high toxic elements contents, reduced microbial activity (Ahirwal and Maiti, 2016; Zhou et al., 2017; Wang et al., 2018). These poor soil properties can adversely affect the growth of plants as well as delaying the development of the soil profile and the accumulation of SOC and TN through natural succession (Ahirwal and Maiti, 2018). However, anthropogenic intervention such as artificial revegetation can accelerate the restoration process (Jia et al., 2012; Mukhopadhyay and Masto, 2016).

The effects of mining (Shrestha and Lal, 2011) and reclamation followed by the establishment of forests (Ussiri et al., 2006; Mukhopadhyay and Masto, 2016; Ahirwal et al., 2017a,b; Ahirwal and Maiti, 2018), grasslands (Evanylo et al., 2005; Yang et al., 2015), and croplands (Yuan et al., 2017) on the SOC and TN pools have been assessed in many studies. However, the soils planted under various revegetation patterns have different SOC and TN stocks and sequestration capacities due to their different erosion rates, deposition rates, and the input quantities of aboveand belowground litter (Wei et al., 2009; Maraseni and Pandey, 2014). Thus, selecting optimal revegetation patterns (patterns that are more effective for SOC and TN accumulation) is particularly important for reclamation (Ahirwal et al., 2017a). The optimal revegetation patterns have been shown to be site specific, because of the different nature of the spoil material and geoclimatic condition (Shrestha and Lal, 2007; Chatterjee et al., 2009; Ganjegunte et al., 2009; Shrestha and Lal, 2010; Datta et al., 2015). These differences strongly hinder the application of specific successful reclamation patterns in other areas.

The northwestern Loess Plateau in China is a transition zone between arid and semiarid regions with a fragile environment. During recent decades, land degradation and soil erosion have increased in this region due to the expansion of coal mining. The Chinese government established a series of laws and regulations, such as the "Land Reclamation Regulations" in 1988 (He et al., 1996), in order to improve the regional ecological environment, alleviate land degradation, and promote the sequestration of SOC and TN. Subsequently, the reclamation and revegetation of severely disturbed mining areas has attracted increased attention, and measures have been implemented for artificial revegetation in this region, such as the planting of arbors, bushes, and grasses, and natural vegetation recovery. The effects of revegetation and time on the properties of reclaimed mine soils have been studied widely (Zhao et al., 2013; Wang et al., 2014; Huang et al., 2016; Liu et al., 2017; Yuan et al., 2017). However, there have been few evaluations of the effects of different revegetation patterns on the SOC and TN pools in reclaimed mine soils.

Therefore, in the present study, we determined the SOC and TN concentrations and stocks in reclaimed mine site (RMS) soils and in adjacent undisturbed native sites (UNSs) at the Heidaigou surface coal mine. The construction of this mine began in 1990 and it is the largest surface coal mine in China, with an annual output of 25 million tons (Li et al., 2014). The objectives of this study were: (1) to evaluate the effects of different revegetation patterns on the SOC and TN distributions and stocks in RMS soils; and (2) to assess the changes in the SOC and 
97 TN stocks in RMS soils relative to those in UNS soils.

98

99

100

101

102

103

104

105

106

107

108

109

110

111

112

113

\section{Materials \& Methods}

\section{Study Area}

The study was conducted in Heidaigou surface mine within the Junggar Banner in Erdos on the Loess Plateau, China $\left(39^{\circ} 43^{\prime}-39^{\circ} 49^{\prime} \mathrm{N}\right.$ and $111^{\circ} 13^{\prime}-111^{\circ} 20^{\prime} \mathrm{E}$; Fig. 1), and was approved by the land environmental protection office of Shenhua Group Zhungeer Energy Co. (project number: KZCX2-XB3-13-02). The mine encompasses a total area of $52.11 \mathrm{~km}^{2}$, and the mine elevation is between $1025 \mathrm{~m}$ and $1302 \mathrm{~m}$ above sea level. The site has a temperate continental arid climate with a mean annual temperature of $7.2^{\circ} \mathrm{C}$. The mean annual precipitation is 404.1 $\mathrm{mm}$ (ranging from 213.0 to $459.5 \mathrm{~mm}$ ), with $60-70 \%$ received during the growing season between July and September. The average annual evaporation is $1943.6 \mathrm{~mm}$ and the relative humidity is $58 \%$. The wind is mostly calm, blowing in a north-northwest direction at an average speed of $2.2 \mathrm{~m} \mathrm{~s}^{-1}$. The predominant soil series prior to mining was mainly loess soil (Calcaric Regosol, FAO/UNESCO, 1988).

The mine has six overburden dumps, and the northern dump was selected for this study (Fig. 1). Since 1993, large-scale reclamation and revegetation activities have been implemented at this dump for the purpose of soil ripening, and by 2005 , the reclamation area had reached $1.48 \mathrm{~km}^{2}$. Reclamation comprised of backfilling using the spoil material, applying $1 \mathrm{~m}$ of topsoil (the deep loess parent materials stripped during mining), and leveling to create a flat surface. In the process of reclamation, at least $1 \mathrm{~m}$ of top subsoil (the deep loess parent materials stripped during mining) was applied on the top of the dump and appropriate leveling was conducted to create a flat surface. Four predominant artificial revegetation patterns were selected and compared to the natural recovery pattern to evaluate their effects on SOC and TN accumulation: the planting of arbors (Ar), bushes (Bu), arbor-bush mixtures (AB), and grasslands (Gr). This study was not a replicated field plot experiment or an established design. Therefore, the vegetation types comprising $\mathrm{Ar}, \mathrm{Bu}, \mathrm{AB}$, and $\mathrm{Gr}$ were established at four, four, two, and three typical vegetation collocations, respectively, as pseudo-replications due to the lack of true replicates, with a total of 13 artificially revegetated sites (ARSs). Revegetation at these selected ARSs was implemented between 2002 and 2005. The vegetation was sparse and it only included scattered Leymus chinensis (Trin.) Tzvel. and Leymus secalinus (Georgi) Tzvel., so only one experimental site was established for the natural recovery approach and it was designated as the natural recovery site (NRS). The NRS was not planted and it had been unmanaged since 2004. All of the selected RMSs had similar soils and terrain conditions, which provided an excellent opportunity to compare the different revegetation patterns. The UNSs located within $2 \mathrm{~km}$ of the reclaimed dump and without significant disturbance due to mining activities were included in the study as reference sites. Historically, the UNSs were mainly sloping farmlands, which were later converted into forests or grasslands due to the implementation of the state-funded "Grain-forGreen project" in 1999. Three Bu sites, two AB sites, and three Gr sites with vegetation type changes since approximately 2001 were selected for this study. In total, 22 experimental sites were established in this study (Fig. 1). Global Positioning System coordinates (with a resolution 
137

138

139

140

141

142

143

144

145

146

147

148

149

150

151

152

153

154

155

156

157

158

159

160

161

162

163

164

165

166

167

168

169

170

171

172

173

of $3 \mathrm{~m}$ ) were recorded for each sampling location, and the details of these sites are shown in Table 1.

\section{Soil sampling and analysis}

At each RMS and UNS, disturbed soil samples were collected at depths of 0-10, 10-20, 20-40, 40-60, and 60-100 cm from five randomly selected locations using a $20 \mathrm{~cm}$ by $5 \mathrm{~cm}$ soil auger in July 2015. The selected replicate locations were at least $20 \mathrm{~m}$ from the boundary of the site (from the area where the vegetation type changed) and they were separated by a distance of approximately $10 \mathrm{~m}$ to account for spatial variability. Soil samples were collected from $\mathrm{Ar}, \mathrm{Bu}$, and $\mathrm{AB}$ sites near the center of the inter-tree space. In total, 550 soil samples were collected. The soil samples were air-dried, crushed, and passed through $0.25-\mathrm{mm}$ sieves before performing SOC and TN measurements. The SOC concentration $\left(\mathrm{g} \mathrm{kg}^{-1}\right)$ was measured using the WalkleyBlack method (Nelson and Sommers, 1982), and the TN concentration $\left(\mathrm{g} \mathrm{kg}^{-1}\right)$ was determined using the semi-macro Kjeldahl method (Bremner and Mulvaney, 1982).

One $1 \mathrm{~m}$ deep pit was dug at one typical site of each vegetation type in the RMS and UNS, and core samples of undisturbed soil $\left(100 \mathrm{~cm}^{3}\right)$ were collected at depths of $0-10,10-20,20-40$, 40-60, and 60-100 cm. Three replicate measurements were conducted in each layer. The soils were transported to the laboratory and dried to a constant weight at $105^{\circ} \mathrm{C}$ to calculate the bulk density $\left(\mathrm{g} \mathrm{cm}^{-3}\right)$. The SOC stock $\left(\mathrm{SOC}_{i}\right)$ and $\mathrm{TN}$ stock $\left(\mathrm{TN}_{i}\right)\left(\mathrm{kg} \mathrm{m}^{-2}\right)$ were then calculated using the following formula:

$S O C_{s}=\sum \frac{S O C_{i} \times B D_{i} \times d_{i}}{100}$

$$
T N_{s}=\sum \frac{T N_{i} \times B D_{i} \times d_{i}}{100}
$$

where $\mathrm{SOC}_{i}, \mathrm{TN}_{i}, \mathrm{BD}_{i}$, and $\mathrm{d}_{i}$ represent the $\mathrm{SOC}$ concentration $\left(\mathrm{g} \mathrm{kg}^{-1}\right)$, TN concentration $\left(\mathrm{g} \mathrm{kg}^{-}\right.$ $\left.{ }^{1}\right)$, bulk density $\left(\mathrm{g} \mathrm{cm}^{-3}\right)$, and thickness $(\mathrm{cm})$ of the $i$ th layer, respectively.

At each RMS and UNS, aboveground leaf litter was also collected from five randomly selected quadrants measuring $1 \mathrm{~m} \times 1 \mathrm{~m}$. The leaf litter was placed in mesh bags and transported to the laboratory to determine the dry mass $\left(\mathrm{g} \mathrm{m}^{-2}\right)$ by weighing the litter after oven drying at $60^{\circ} \mathrm{C}$ for $48 \mathrm{~h}$.

\section{Statistical analysis}

All data were tested for normality and homogeneity of variance. One-way analysis of variance (ANOVA) and least significant difference (LSD) tests $(p<0.05)$ were used to detect differences in the concentrations and stocks of SOC and TN associated with different revegetation patterns and soil depths. Few typical vegetation collocations were available for each land and the NRS was not field replicated, so the five sampling locations within each site were also used as pseudoreplicates for the statistical analysis. The independent sample $t$-test was applied to compare the concentrations and stocks of SOC and TN between RMSs and UNSs, and only the soil values obtained at the $\mathrm{Bu}, \mathrm{AB}$, and $\mathrm{Gr}$ sites were used. All statistical analyses were performed using SPSS 16.0 software. 


\section{Results}

\section{SOC and TN concentrations under different revegetation patterns}

The concentrations of SOC and TN in the soil profile are shown in Table 2. The SOC concentration was strongly stratified based on soil depth for all of the revegetation patterns. The SOC concentrations were highest near the surface $(0-10 \mathrm{~cm}$ depth) and decreased as the soil depth increased, although a slight increase was observed at a depth of $60-100 \mathrm{~cm}$ for $\mathrm{Bu}$ and $\mathrm{AB}$. Significant decreases occurred in the $0-40 \mathrm{~cm}$ depth for $\mathrm{Gr}$ and the $0-20 \mathrm{~cm}$ depth for the other four vegetation types. The SOC concentration did not differ significantly below $40 \mathrm{~cm}$ or $20 \mathrm{~cm}$. As shown in Table 2, the revegetation pattern had a significant effect on the SOC concentration $(p<0.05)$. At a depth of $0-40 \mathrm{~cm}$, the average SOC concentration ranged from $3.54 \mathrm{~g} \mathrm{~kg}^{-1}$ for Gr to $1.50 \mathrm{~g} \mathrm{~kg}^{-1}$ for NRS and it was ranked in the following order: $\mathrm{Gr}>\mathrm{Bu}>\mathrm{AB}>\mathrm{Ar}>\mathrm{NRS}$. The average SOC concentrations $(0-40 \mathrm{~cm})$ for $\mathrm{Gr}, \mathrm{Bu}, \mathrm{AB}$ and $\mathrm{Ar}$ were approximately $136.5 \%$, $74.4 \%, 55.9 \%$, and $21.5 \%$ greater, respectively, than that for the NRS. Except for AB at depths of 10-20 and $20-40 \mathrm{~cm}$ and Ar, the SOC concentrations in the ARSs were significantly higher than those in the NRS. Among the ARSs, Gr contained significantly higher SOC concentrations than all the other revegetation patterns at all depths. The SOC concentration in Ar was significantly lower than that in $\mathrm{Bu}$ at all depths but lower than that in $\mathrm{AB}$ at a depth of 0-10 cm. No significant differences were observed between $\mathrm{Bu}$ and $\mathrm{AB}$ at any depth. Below $40 \mathrm{~cm}$, the differences in the SOC concentration were smaller among the revegetation patterns. In addition, no significant differences were found between the ARSs and the NRS, except for Gr. Gr had the highest SOC concentration among the revegetation sites, it did not differ significantly from those in $\mathrm{AB}$ and $\mathrm{Bu}$. In addition, no differences were observed between $\mathrm{Ar}, \mathrm{Bu}$, and $\mathrm{AB}$.

The soil TN concentration also varied significantly according to the soil depth and revegetation pattern $(p<0.05$, Table 2$)$. The TN concentration exhibited a significant decreasing trend from $0-40 \mathrm{~cm}$ for $\mathrm{Ar}, \mathrm{Bu}$, and $\mathrm{Gr}$ and from $0-20 \mathrm{~cm}$ for $\mathrm{AB}$ and the NRS. The soil TN concentration in the $0-40 \mathrm{~cm}$ interval exhibited a similar trend to that of SOC and it was ranked in the following order: $\mathrm{Gr}>\mathrm{Bu}>\mathrm{AB}>\mathrm{Ar}>\mathrm{NRS}$. The TN concentrations in the ARSs with $\mathrm{Bu}$ and $\mathrm{Gr}$ at all depths and with $\mathrm{AB}$ at a depth of $0-10 \mathrm{~cm}$ were significantly greater than those in the NRS, which was consistent with the SOC results. However, unlike SOC, the highest soil TN concentration in $\mathrm{Gr}$ was observed in the $0-20 \mathrm{~cm}$ depth. The differences among the vegetation types decreased below $40 \mathrm{~cm}$ and no differences were observed below $60 \mathrm{~cm}$.

\section{SOC and TN stocks under different revegetation patterns}

The average SOC stock varied from 085 to $2.01 \mathrm{~kg} \mathrm{~m}^{-2}$ in the top $0-40 \mathrm{~cm}$ of the soil and from 1.80 to $3.78 \mathrm{~kg} \mathrm{~m}^{-2}$ in the entire soil profile $(0-100 \mathrm{~cm})$ with the different revegetation patterns (Fig. 2). The SOC stock in the $0-40 \mathrm{~cm}$ depth accounted for $43.4-53.3 \%$ of the total SOC stock in the 0-100 cm depth. Except for those in Ar, the SOC stocks in the ARSs were significantly greater than those in the NRS in both the $0-40 \mathrm{~cm}$ and $0-100 \mathrm{~cm}$ depths. The total SOC stocks at $100 \mathrm{~cm}$ with $\mathrm{Bu}, \mathrm{AB}$, and $\mathrm{Gr}$ were $51.4 \%, 59.9 \%$, and $109.9 \%$ higher, respectively, compared with that in the NRS. Gr had the highest SOC stocks, which were $38.7 \%$ and $31.3 \%$ higher than those for $\mathrm{Bu}$ and $\mathrm{AB}$, respectively, at a depth of $0-100 \mathrm{~cm}$. However, the $\mathrm{SOC}$ stocks 
214

215

216

217

218

219

220

221

222

223

224

225

226

227

228

229

230

231

232

233

234

235

236

237

238

239

240

241

242

243

244

245

246

247

248

249

250

251

252

253

in $\mathrm{Bu}$ and $\mathrm{AB}$ were not significantly different.

The average soil TN stocks varied between 0.10 and $0.18 \mathrm{~kg} \mathrm{~m}^{-2}$ in the $0-40 \mathrm{~cm}$ interval and between 0.22 and $0.34 \mathrm{~kg} \mathrm{~m}^{-2}$ in the $0-100 \mathrm{~cm}$ interval (Fig. 2). The TN stock in the $0-20 \mathrm{~cm}$ depth accounted for $45.0-51.2 \%$ of the total TN stock in the $0-100 \mathrm{~cm}$ depth. Similar to the SOC stocks, the TN stocks were higher in the ARSs than those in the NRS, excluding those in Ar. Gr had significantly higher TN stocks compared with $\mathrm{Bu}$ and $\mathrm{AB}$, but the TN stocks did not differ between $\mathrm{Bu}$ and $\mathrm{AB}$.

\section{Comparison of SOC and TN concentrations and stocks in RMSs and UNSs}

As shown in Fig. 3 and Fig. 4, there were significant differences in the SOC and TN concentrations and stocks between the RMSs and UNSs $(p<0.05)$. The average SOC concentration in the 0-100 cm interval was lower in the RMSs than that in the UNSs , i.e., $24.8 \%$ lower for $\mathrm{Bu}, 30.5 \%$ lower for $\mathrm{AB}$, and $31.0 \%$ lower for $\mathrm{Gr}$. However, the differences in the SOC concentrations between the RMSs and UNSs varied among the vegetation types and soil depths, but a significant difference was only observed for $\mathrm{AB}$ and $\mathrm{Gr}$, and it was mainly in the 0$20 \mathrm{~cm}$ soil interval. From $0-20 \mathrm{~cm}$, the RMSs contained significantly lower SOC stocks than the UNSs for AB and Gr, but the SOC stocks were similar to those in the UNSs for Bu. However, in the $0-100 \mathrm{~cm}$ interval, there were no significant differences in the SOC stocks between the RMSs and UNSs for all vegetation types.

The mean TN concentration in the $0-100 \mathrm{~cm}$ soil interval was lower in the RMSs than the UNSs, i.e., 29.4\% lower for $\mathrm{Bu}, 27.8 \%$ lower for AB, and $43.1 \%$ lower for Gr (Fig. 3). In particular, the RMSs had significantly lower TN concentrations than the UNSs up to a depth of $100 \mathrm{~cm}$ for $\mathrm{Bu}$ and $\mathrm{Gr}$ and up to a depth of $40 \mathrm{~cm}$ for AB. In contrast to the SOC, the TN stocks in the RMSs were significantly lower than those in the UNSs in both the $0-20 \mathrm{~cm}$ and $0-100 \mathrm{~cm}$ intervals (Fig. 4).

\section{Comparison of aboveground plant litter in RMSs and UNSs}

There were significant differences in the amounts of aboveground plant litter between the RMSs and UNSs $(p<0.05)$. The amounts in the ARSs were significantly higher than those in the UNSs for most cases, whereas the amounts in the NRS were significantly lower than those in the UNSs. Among the ARSs, the woodlands, i.e., A, B, and AB, had significantly higher amounts of aboveground plant litter than the grassland, i.e., G. However, no significant differences were found among the $\mathrm{A}, \mathrm{B}$, and $\mathrm{AB}$.

\section{Discussion}

Previous studies have demonstrated that surface mining and the initial stage of reclamation can result in significant losses of SOC and TN, mainly due to topsoil loss, mechanical mixing of the soil horizons, breakdown of soil aggregates, enhanced mineralization, erosion, leaching from the exposed soil surface, and the lack of new vegetation (Shrestha and Lal, 2011; Zhou et al., 2017; Ahirwal et al., 2018; Yuan et al., 2018). Li et al. (2014) investigated the SOC and TN stocks in a newly constructed dump (with the same soil reconstruction practices as the northern dump but it was not revegetated) at the Heidaigou surface coal mine. In their study, the SOC stocks in the dump were 0.38 and $1.51 \mathrm{~kg} \mathrm{~m}^{-2}$ in the $0-20 \mathrm{~cm}$ and $0-100 \mathrm{~cm}$ intervals, 
254 respectively, and the TN stock was 0.03 and $0.15 \mathrm{~kg} \mathrm{~m}^{-2}$. These values represent losses of $69.8 \%$

255 and $66.7 \%$ for the SOC in the $0-20 \mathrm{~cm}$ and $0-100 \mathrm{~cm}$ intervals, respectively, and $76.9 \%$ and $65.9 \%$

256 for the TN compared with the mean values obtainted for the UNSs in our study (Fig. 4). The

257 large and relatively rapid declines in the SOC and TN pools indicate a high potential for C and N

258 accumulation in mine soils under appropriate reclamation practices (Vindušková and Frouz, 2013;

259 Mukhopadhyay and Masto, 2016; Ahirwal et al., 2017a). It has been reported that soils with a

260 high potential for accumulating $\mathrm{C}$ and $\mathrm{N}$ are those with $\mathrm{C}$ and $\mathrm{N}$ contents below their carrying

261 capacities, i.e., young soils or soils where $\mathrm{C}$ and $\mathrm{N}$ have been depleted because of management

262 practices, such as dramatically disturbed mine soils (Glenn, 1998; Zhang et al., 2018).

263

264

Vegetation plays a major role in improving the properties of mine soils, where increased

265 biomass production, root residues and exudates, and the greater activity of microbes and fauna following revegetation have positive effects on the accumulation of SOC and TN in RMSs (Huang et al., 2016; Zhou et al., 2017; Yuan et al., 2018). In agreement with previous studies (Ahirwal et al., 2017a; Ahirwal and Maiti, 2018), we found that the increases in the SOC and TN stocks were more pronounced in the top layer $(0-20 \mathrm{~cm})$, where approximately one-third of the SOC and TN stocks were present. The SOC and TN stocks increased by $118.3 \%$ and $176 \%$, respectively, in the 0-20 cm depth at the RMSs after 10-13 years of reclamation, compared with the stocks measured at the newly constructed dump (Li et al., 2014). The changes in the SOC and TN stocks agreed with the results of obtained by Ahirwal et al. (2017b), who reported that the SOC and TN stocks in the $0-30 \mathrm{~cm}$ depth of a reclaimed mine soil increased two times after 711 years of revegetation. These results also confirm the effects of revegetation on the accumulation of SOC and TN.

The SOC and TN dynamics as well as the potential of accumulating SOC and TN in mine soils are strongly related to revegetation patterns (Chatterjee et al., 2009; Ganjegunte et al., 2009; Shrestha and Lal, 2010; Datta et al., 2015). In the present study, the SOC and TN concentrations and stocks were significantly greater in the ARSs than the NRS (especially in the top 0-40 cm soil layer). Liu et al (2019) also found that the organic matter level in the 5-30 cm depth was significantly higher in ARSs (8.75\%) than in an NRS (4.72\%) in the Shendong mining area of China, which may have been due to the rapid growth of vegetation and biomass accumulation in the ARSs, thereby increasing the SOC and TN inputs from plant litter and root residues (Liu et al., 2019). Indeed, more plant litter (broken branches and fallen leaves) was found on the ground surface at the ARSs in our study (Fig. 5). Moreover, Liu et al. (2019) reported that the microbial activity was higher in the RMSs, which was beneficial for the decomposition of plant residues, thereby leading to higher SOC and TN levels. However, the restoration of the soil quality in the disturbed mine land via natural succession is usually challenging because of its disordered stratigraphic sequence, server compaction, complicated surface materials, and degraded soil properties (Zhou et al., 2017; Ahirwal and Maiti, 2018; Yuan et al., 2018). Bradshaw (1997) estimated that it may take 50-100 years to restore the soil quality of a disturbed mine land to a similar state as the native soil by natural succession.

Among the artificial revegetation approaches, grasslands were more beneficial for the accumulation of SOC and TN than woodlands at the reclamation sites, especially in the top 40 
295

296

297

298

299

300

301

302

303

304

305

306

307

308

309

310

311

312

313

314

315

316

317

318

319

320

321

322

323

324

325

326

327

328

329

330

331

332

333

334

335

$\mathrm{cm}$ of the soil. This result is consistent with those obtained by Shrestha and Lal (2007), who showed that the SOC and TN contents of pasture lands were 99\% and 98\% higher than those of forested lands, respectively, at a 28-year-old reclaimed mine. These different capacities of soils for SOC and TN storage can probably be attributed to the changes in the amounts and forms of organic matter in the topsoil under different vegetation types (Wei et al., 2009), as well as the local climate conditions (Mukhopadhyay and Masto, 2016). In the woodlands, litterfall on the soil surface is the source of primary organic matter input in the topsoil, whereas the major organic matter input source is the decomposition of belowground roots in grasslands (Guo and Gifford, 2002; Wei et al., 2009). This study area was arid with little precipitation, so the soil water supply was restricted to shallow soil horizons, which is more suitable for the growth and development of grasses. Grasses rapidly increase the root biomass and litter production, especially the growth of fine roots, which can fix large amounts of SOC and TN and transfer SOC and TN to the topsoil (Jackson et al., 1997). Guo et al. (2007) found that approximately 3.6 $\mathrm{Mg} \mathrm{C} \mathrm{ha}{ }^{-1}$ and $81.4 \mathrm{Mg} \mathrm{N} \mathrm{ha}^{-1}$ were contributed annually to the soil under a native pasture due to fine root mortality. Moreover, the reduced exchange of water and gases in grasslands because of the dense root network may reduce the turnover rate of SOC and TN (Yakimenko, 1998). By contrast, coarse roots represent most of the standing root crops in woodlands, which do not die and decompose for many years; thus, root production and turnover are of minor significance (Guo et al., 2007). Although woodlands can produce more aboveground plant litter on the soil surface, the litter may prohibit precipitation from permeating into the mineral soil, which may facilitate the decomposition of organic matter and soil respiration but limit the plant uptake of precipitation (He et al., 2008). In addition, despite the comparable amounts of aboveground plant litter, arbor planting resulted in significantly lower SOC and TN values compared with those associated with shrubs, which was largely due to the microclimate. Compared with the exposed arbor lands, the low stocks and high canopy density of the bush lands created a more humid environment, which is beneficial for the accumulation of SOC and TN following forestation (Paul et al., 2003; Wei et al., 2009).

Overall, the SOC and TN concentrations in the deep soil intervals (below $40 \mathrm{~cm}$ ) varied little among the revegetation patterns. Similarly, previous studies also indicated that the SOC and TN differences between vegetation types decreased with the soil depth (Datta et al., 2015), which may be attributed to the reduced residue inputs in the deep soil, especially those in the form of fine roots. Zhang et al. (2011) reported that the distribution of fine roots agreed with the distributions of SOC and TN. On the northern Loess Plateau, Wei et al. (2009) found that fine roots were mainly distributed in the $0-40 \mathrm{~cm}$ interval, and they accounted for $72 \%-94 \%$ of the fine roots in the $0-100 \mathrm{~cm}$ interval.

After reclamation for 10-13 years, the SOC and TN levels in the RMSs were still lower than those in the UNSs (only considering the shared vegetation types, i.e., Bu, AB, and Gr). The SOC stocks in the RMSs and UNSs only differed in the top $0-20 \mathrm{~cm}$ of the soil, but the differences were not significant when the entire soil profile $(0-100 \mathrm{~cm})$ was considered, and similar results were obtained by Chatterjee et al. (2009). Based on the entire soil profile, the SOC concentrations in the RMSs were lower than those in the UNSs in the present study, i.e., by $24.8 \%$ -

Peer) reviewing PDF | (2019:08:40756:1:2:NEW 19 Dec 2019) 
$33631 \%$, and the TN concentrations were 27.8\%-43.1\% lower. Similarly, Ahirwal et al. (2017b)

337 reported that the SOC and TN levels determined at reclaimed sites after 11 years of reclamation

338 were approximately $75 \%$ and $39 \%$ of those at the reference forest site, respectively. These results

339 indicat that restoring the original SOC and TN levels after reclamation requires a significant

340 period of time. According to Huang et al. (2016), the SOC and TN levels in a revegetated site

341 may require 23 to 25 years to reach the same levels as those in an undisturbed site. However,

342 Yuan et al. (2018) suggested that the nutrient levels in revegetated sites could reach the same

343 levels as those in undisturbed sites within about 10 year. According to Ussiri and Lal (2005),

344 mining and the associated disturbances disrupt the original SOC and TN equilibrium in the soil,

345 while the accumulation of SOC and TN by appropriate reclamation and management practices

346 promotes stabilization at a new near steady state equilibrium. However, the length of time

347 required to reach the new equilibrium is uncertain. The SOC and TN accumulation rates in

348 reclaimed mine soils depend on the microclimate, physicochemical and biological properties of

349 the mine soils, vegetation type, prevailing management practices, and the time after vegetation

350 establishment (Ahirwal et al., 2017a; Ahirwal and Maiti, 2018). Moreover, the new equilibrium

351 may eventually be similar, lower, or higher than the pre-mining equilibrium (Ussiri and Lal,

352 2005).

\section{Conclusions}

354 Surface mining activities led to dramatic losses of SOC and TN. The results obtained in this

355 study demonstrate that appropriate reclamation approaches such as revegetation could restore the

356 SOC and TN pools in RMSs. However, restoring the original SOC and TN levels after

357 reclamation required a significant amount of time. The effectiveness of restoration varied among

358 the revegetation pattern. The NRS had lower SOC and TN concentrations and stocks compared

359 with those in the ARSs, possibly because of the poor plant growth. Among the vegetation types

360 in the ARSs, the potential for accumulating SOC and TN was higher in Gr than woodlands (Ar,

$361 \mathrm{Bu}$, and $\mathrm{AB}$ ). A comparison of the different woodlands types indicated that $\mathrm{Bu}$ had the largest

362 accumulation potential, and $\mathrm{Ar}$ and $\mathrm{AB}$ had similar potentials. The results suggest that grasslands

363 were more favorable for the accumulation of SOC and TN than woodlands, especially arbor

364 lands, in this arid area.

365 The results of this study have important implications for land reclamation and ecological

366 restoration in the mine areas of Loess Plateau. The planting of grasses such as Leymus chinensis,

367 Leymus secalinus, Medicago sativa, and Artemisia argyi, should be encouraged to facilitate the

368 reclamation of mine soils in this region.

369 Acknowledgements

370 We thank the anonymous reviewers and the journal editors for providing constructive

371 comments and suggestions on the manuscript.

372 References

373 Ahirwal J, Maiti SK. 2016. Assessment of soil properties of different land uses generated due to 
374 surface coal mining activities in tropical Sal (Shorea robusta) forest, India. Catena 140:155-163.

375 Ahirwal J, Maiti SK. 2018. Development of technosol properties and recovery of carbon stock

376 after 16 years of revegetation on coal mine degraded lands, India. Catena 166:114-123.

377 Ahirwal J, Maiti SK., Reddy MS. 2017a. Development of carbon, nitrogen and phosphate

378 stocks of reclaimed coal mine soil within 8 years after forestation with Prosopis juliflora, (Sw.)

379 Dc. Catena 156:42-50.

380 Ahirwal J, Maiti SK, Singh AK. 2017b. Changes in ecosystem carbon pool and soil $\mathrm{CO}_{2}$ flux

381 following post-mine reclamation in dry tropical environment, India. Science of the Total

382 Environment 583:153-162.

383 Bao N, Wu L, Ye B, Yang K, Zhou W. 2017. Assessing soil organic matter of reclaimed soil

384 from a large surface coal mine using a field spectroradiometer in laboratory. Geoderma 288:47-

38555.

386 Bradshaw A. 1997. Restoration of mined lands-using natural processes. Ecological Engineering

387 8: $255-269$.

388 Bremner JM., Mulvaney CS. 1982. Nitrogen-total. Agronomy Monograph 9. In: Page AL,

389 Miller RH, Keeney DR, eds. Methods of soil analysis, part 2, chemical and microbial properties.

390 Madison, Agronomy Society of America, 595-624.

391 Cao YG, Wang JM, Bai ZK, Zhou W, Zhao ZQ, Ding X, Li YN. 2015. Differentiation and

392 mechanisms on physical properties of reconstructed soils on open-cast mine dump of loess area.

393 Environmental Earth Sciences 74: 6367-6380.

394 Chatterjee A, Lal R, Shrestha RK, Ussiri DAN. 2009. Soil carbon pools of reclaimed

395 minesoils under grass and forest land uses. Land Degradation \& Development 20:300-307.

396 Datta A, Basak N, Chaudhari SK, Sharma DK. 2015. Soil properties and organic carbon

397 distribution under different land uses in reclaimed sodic soils of north-west India. Geoderma

398 Regional 4:134-146.

399 Evanylo GK, Abaye AO, Dundas C, Zipper CE, Lemus R, Sukkariyah B, Rockett J. 2005.

400 Herbaceous vegetation productivity, persistence, and metals uptake on a biosolids-amended mine

401 soil. Journal of Environment Quality 34:1811-1819.

402 FAO/UNESCO. 1988. Soil map of the world, revised legend. FAO/UNESCO, Rome.

403 Ganjegunte GK, Wick AF, Stahl PD, Vance GF. 2009. Accumulation and composition of total 404 organic carbon in reclaimed coal mine lands. Land Degradation \& Development 20:156-175.

405 Glenn E, Squires V, Olsen M, Frye R. 1993. Potential for carbon sequestration in the drylands.

406 Water Air and Soil Pollution 70:341-355.

407 Guo LB, Gifford RM. 2002. Soil carbon stocks and land use change: a meta analysis. Global

408 Change Biology 8:345-360.

409 Guo LB, Wang MB, Gifford RM. 2007. The change of soil carbon stocks and fine root

410 dynamics after land use change from a native pasture to a pine plantation. Plant and Soil

411 299:251-262.

412 He NP, Yu Q, Wu L, Wang YS, Han XG. 2008. Carbon and nitrogen store and storage

413 potential as affected by land-use in a Leymus chinensis grassland of northern China. Soil Biology

414 Biochemistry 40:2952-2959. 
415 He SJ, Guo HC, Wei ZY, Liu H. 1996. A study on the land restoration in coal mining fields in 416 China. Geographical Research 15:23-32.

417 Huang L, Zhang P, Hu YG, Zhao Y. 2016. Vegetation and soil restoration in refuse dumps 418 from open pit coal mines. Ecological Engineering 94:638-646.

419 Jackson RB, Mooney H, Schulze ED. 1997. A global budget for fine root biomass, surface area, and nutrient contents. Proceedings of the National Academy of Sciences 94:7362-7366. Jia XX, Wei XR, Shao MA, Li XZ. 2012. Distribution of soil carbon and nitrogen along a revegetational succession on the Loess Plateau of China. Catena 95:160-168. Lal R. 2004. Soil carbon sequestration impacts on global climate change and food security. Science 304: 1623-1627. reclamation under vegetation reconstruction on opencast coal mine dump. Environmental

\section{Liu XY, Bai ZK, Zhou W, Cao YG, Zhang GJ. 2017. Changes in soil properties in the soil} profile after mining and reclamation in an opencast coal mine on the loess plateau, china. Ecological Engineering 98:228-239.

Liu Y, Lei SG, Gong CG. 2019. Comparison of plant and microbial communities between an artificial restoration and a natural restoration topsoil in coal mining subsidence area.

Environmental Earth Sciences 78:204.

Maraseni TN, Pandey SS. 2014. Can vegetation types work as an indicator of soil organic carbon? An insight from native vegetations in Nepal. Ecological Indicators 46:315-322.

Mukhopadhyay S, Masto RE. 2016. Carbon storage in coal mine spoil by Dalbergia sissoo Roxb. Geoderma 284:204-213.

Nelson DW, Sommers LE. 1982. Total carbon, organic carbon, and organic matter. Agronomy Monograph 9. In: Page AL, Miller RH, Keeney DR, eds. Methods of soil analysis, part 2, chemical and microbial properties. Madison, Agronomy Society of America, 539-552.

\section{Paul KI, Polglase PJ, Richards GP. 2003. Predicted change in soil carbon following}

afforestation or reforestation, and analysis of controlling factors by linking a $\mathrm{C}$ accounting model (CAMFor) to models of forest growth (3PG), litter decomposition (GENDEC) and soil C turnover (RothC). Forest Ecology and Management 177:485-501.

Shrestha RK, Lal R. 2007. Soil carbon and nitrogen in 28-year-old land uses in reclaimed coal mine soils of Ohio. Journal of Environmental Quality 36:1775-1783.

Shrestha RK, Lal R. 2008. Land use impacts on physical properties of 28 years old reclaimed mine soils in Ohio. Plant and Soil 306:249-260.

Shrestha RK, Lal, R. 2010. Carbon and nitrogen pools in reclaimed land under forest and pasture ecosystems in Ohio, USA. Geoderma 157:196-205.

Shrestha RK, Lal R. 2011. Changes in physical and chemical properties of soil after surface mining and reclamation. Geoderma 161:168-176.

Ussiri DAN, Lal R. 2005. Carbon sequestration in reclaimed minesoils. Critical Reviews in Plant Sciences 24:151-165.

Ussiri DAN, Lal R, Jacinthe PA. 2006. Soil properties and carbon sequestration of afforested 
456 pastures in reclaimed minesoils of Ohio. Soil Science Society of America Journal 70:1797-1806.

457 Vindušková O, Frouz J. 2013. Soil carbon accumulation after open-cast coal and oil shale

458 mining in northern hemisphere: a quantitative review. Environmental Earth Sciences 69:1685-

4591698.

460 Wang JM, Jiao ZZ, Bai ZK. 2014. Changes in carbon sink value based on RS and GIS in the

461 Heidaigou opencast coal mine. Environmental Earth Sciences 71:863-871.

462 Wang JM, Qin Q, Guo LL, Feng Y. 2018. Multi-fractal characteristics of three-dimensional

463 distribution of reconstructed soil pores at opencast coal-mine dump based on high-precision CT

464 scanning. Soil and Tillage Research 182:144-152.

465 Wei XR, Shao MA, Fu XL, Horton R, Li Y, Zhang XC. 2009. Distribution of soil organic C,

$466 \mathrm{~N}$ and $\mathrm{P}$ in three adjacent land use patterns in the northern Loess Plateau, China.

467 Biogeochemistry 96:149-162.

468 Yakimenko EY. 1998. Soil comparative evolution under grasslands and woodlands in the forest

469 zone of Russia. In: Lal R, Kimble JM, Follett RF, Stewart BA, eds. Management of Carbon

470 Sequestration in Soils. CRC Press, Boca Raton, 391-404.

471 Yang Z, Hao HM, Wang D, Chang XF, Zhu YJ, Wu GL. 2015. Revegetation of artificial

472 grassland improve soil organic and inorganic carbon and water of abandoned mine. Journal of

473 Soilence \& Plant Nutrition 15:629-638.

474 Yuan Y, Zhao ZQ, Li XZ, Wang YY, Bai ZK. 2018. Characteristics of labile organic carbon

475 fractions in reclaimed mine soils: Evidence from three reclaimed forests in the Pingshuo

476 opencast coal. Science of the Total Environment 613-614:1196-1206.

477 Yuan Y, Zhao ZQ, Zhang PF, Chen LM, Hu T, Niu SY, Bai ZK. 2017. Soil organic carbon

478 and nitrogen pools in reclaimed mine soils under forest and cropland ecosystems in the loess

479 plateau, china. Ecological Engineering 102:137-144.

480 Zhang C, Xue S, Liu GB, Song ZL. 2011. A comparison of soil qualities of different

481 revegetation types in the Loess Plateau, China. Plant and Soil 347:163-178.

482 Zhang JY, Sun CL, Liu GB, Xue S. 2018. Effects of long-term fertilisation on aggregates and 483 dynamics of soil organic carbon in a semi-arid agro-ecosystem in china. Peerj 6: e4758.

484 Zhang H, Wu PB, Fan MM, Zheng SY, Wu JT, Yang XH, Zhang M, Yin AJ, Gao C. 2018.

485 Dynamics and driving factors of the organic carbon fractions in agricultural land reclaimed from 486 coastal wetlands in eastern china. Ecological Indicators 89:639-647.

487 Zhao ZQ, Shahrour I, Bai ZK, Fan WX, Feng LR, Li HF. 2013. Soils development in 488 opencast coal mine spoils reclaimed for 1-13 years in the west-northern Loess Plateau of China. 489 European Journal of Soil Biology 55:40-46.

490 Zhou W, Yang K, Bai Z, Cheng H, Liu F. 2017. The development of topsoil properties under 491 different reclaimed land uses in the pingshuo opencast coalmine of loess plateau of china.

492 Ecological Engineering 100:237-245. 


\section{Figure 1}

Locations of sampling sites at the Heidaigou surface mine on the Loess Plateau, China.

The yellow, blue, green, red, and pink symbols represent the sites planted with trees, bushes, arbor-bush mixtures, grasses, and the natural recovery site, respectively. Map credit: (C) Maxar Technologies and Google Earth. 

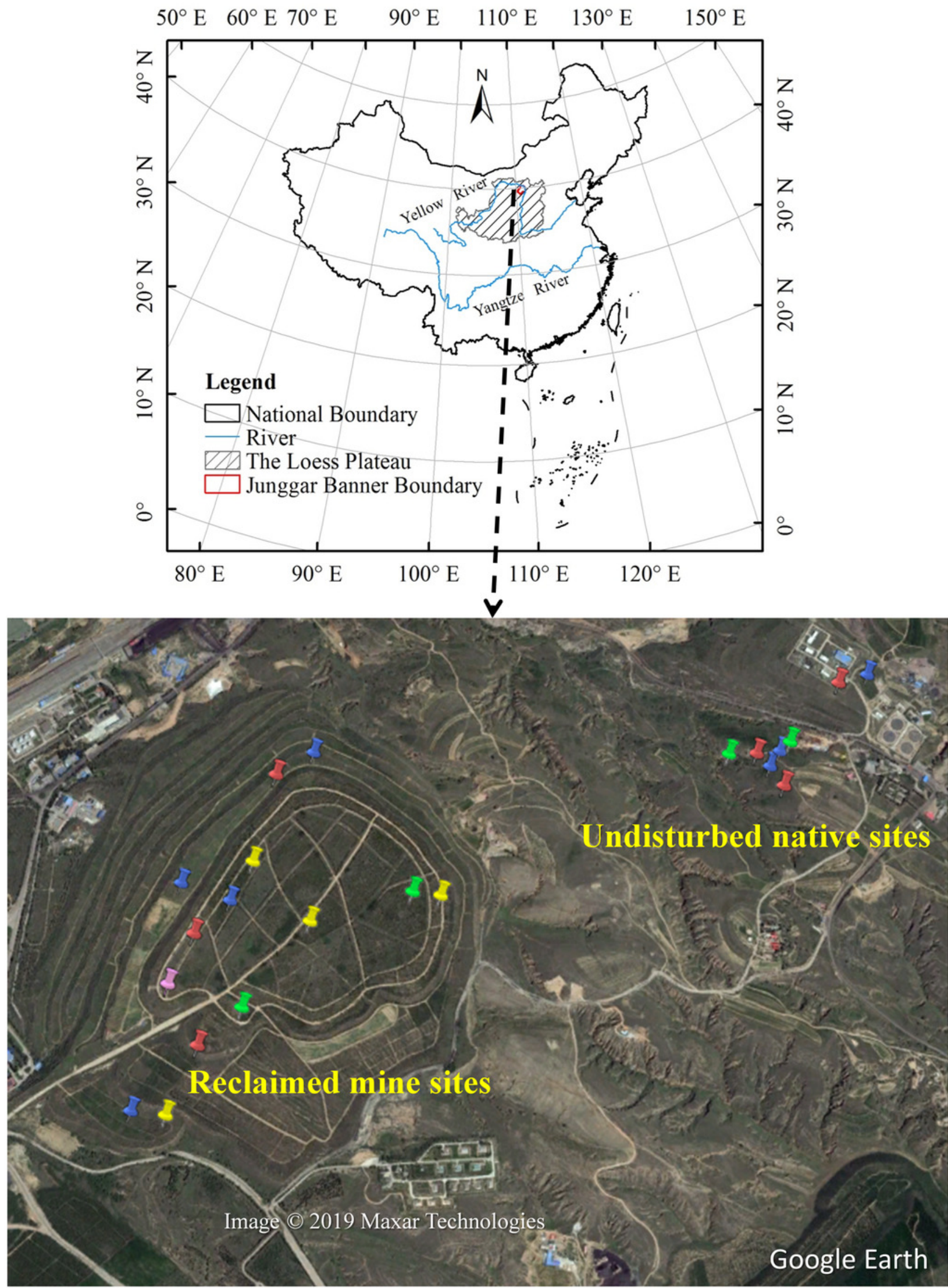
Figure 2

Soil organic carbon (SOC) and total nitrogen (TN) stocks $\left(\mathrm{kg} \mathrm{m}^{-2}\right)$ at $0-20$ and $0-100 \mathrm{~cm}$ soil depths under different revegetation patterns.

Different lowercase letters denote significant differences between revegetation patterns ( $p<$ 0.05). Error bars show the standard deviation. 
(A)

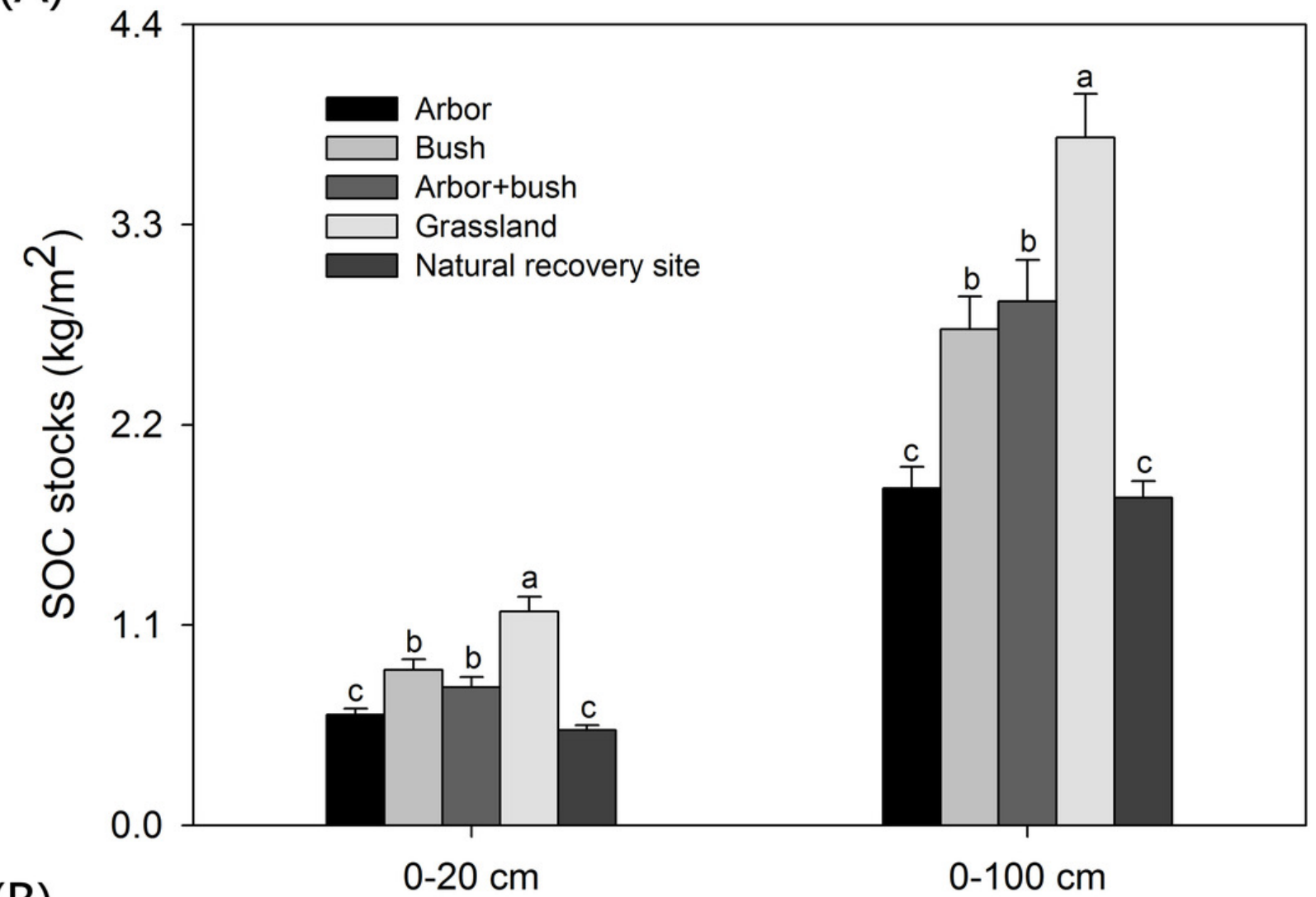

(B)

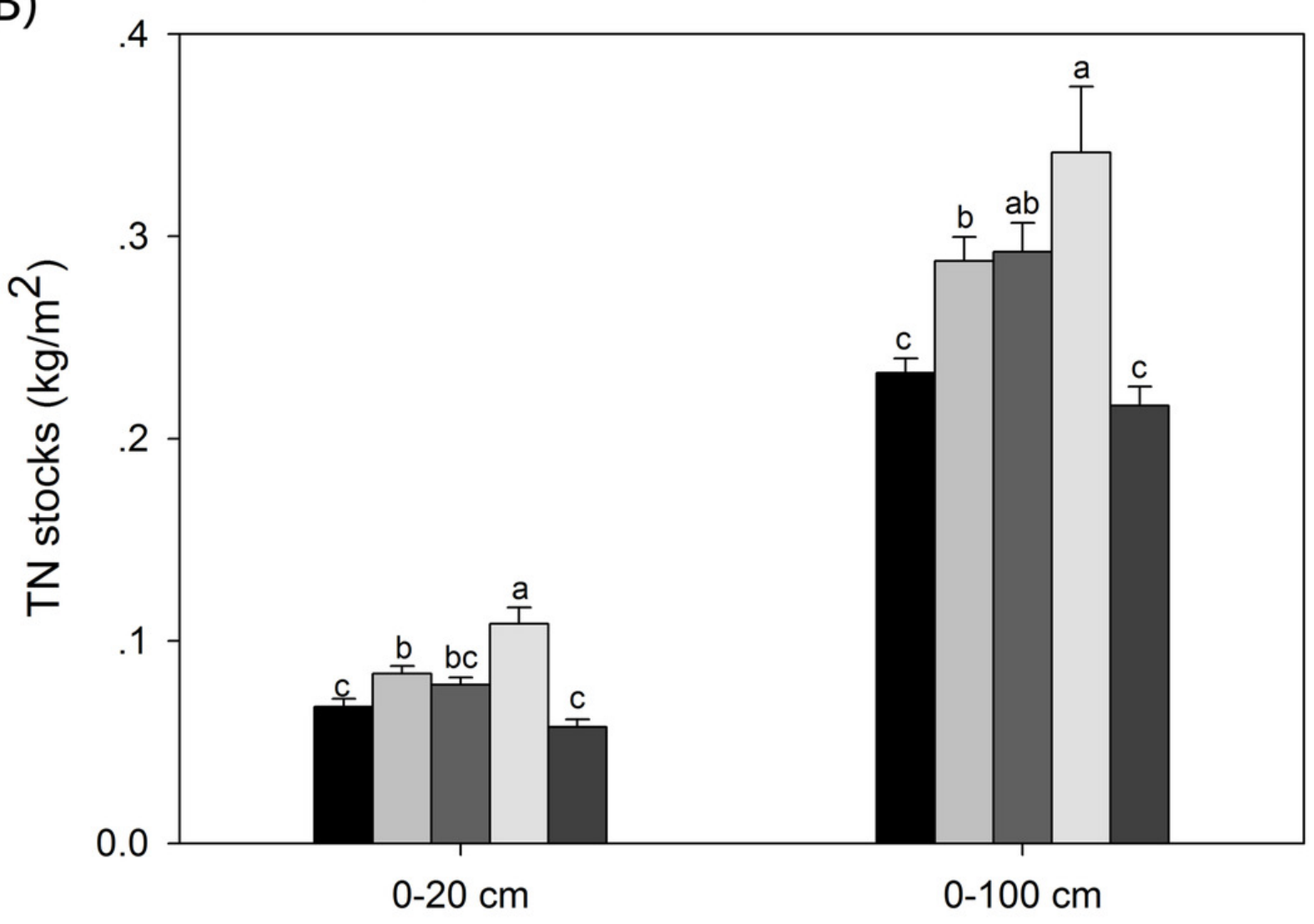


Figure 3

Comparison of SOC and TN concentrations $\left(\mathrm{g} \mathrm{kg}^{-1}\right)$ in reclaimed mine sites (RMSs) and undisturbed native sites (UNSs) under different vegetation types (Bu: bushes, AB: arborbush mixtures, and Gr: grasslands).

** and * represent significant differences between RMSs and UNSs at $p<0.01$ and $p<0.05$, respectively. Error bars show the standard deviations. 
(A) SOC concentration $\left(\mathrm{g} \mathrm{kg}^{-1}\right)$

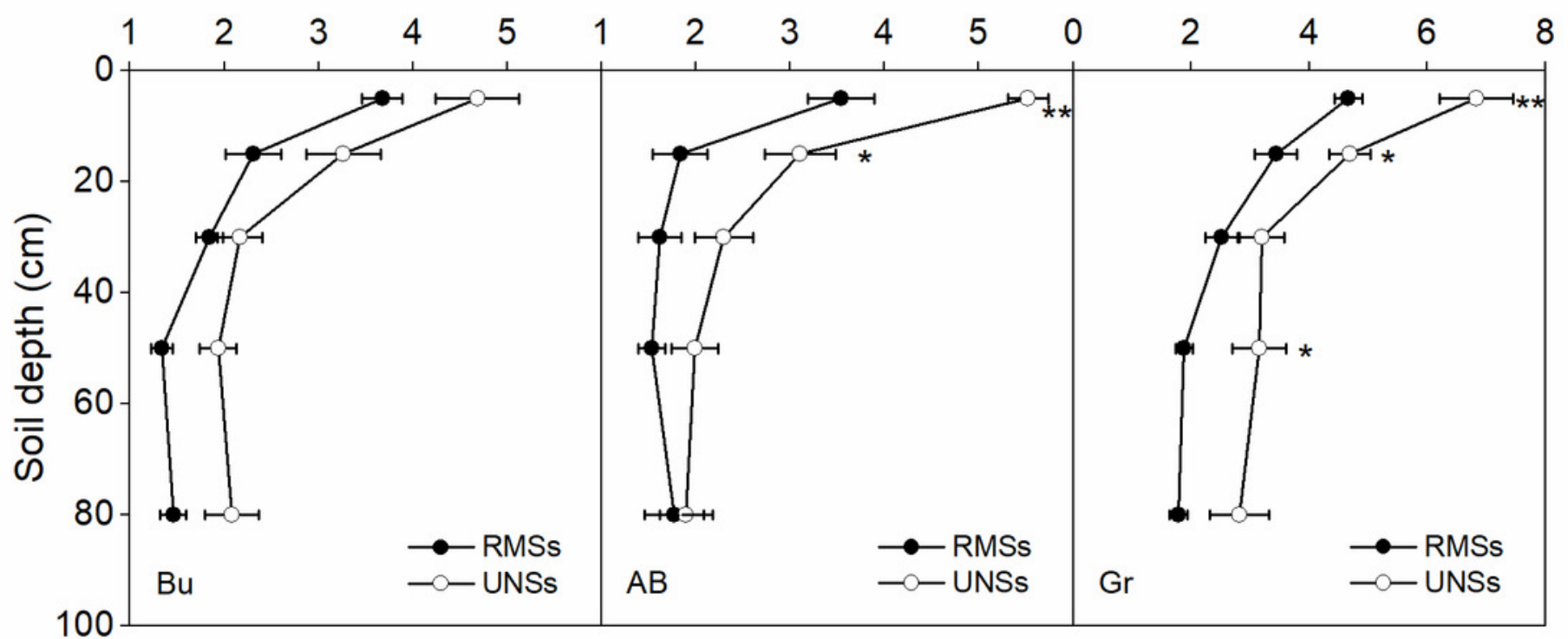

(B)

TN concentration $\left(\mathrm{g} \mathrm{kg}^{-1}\right)$

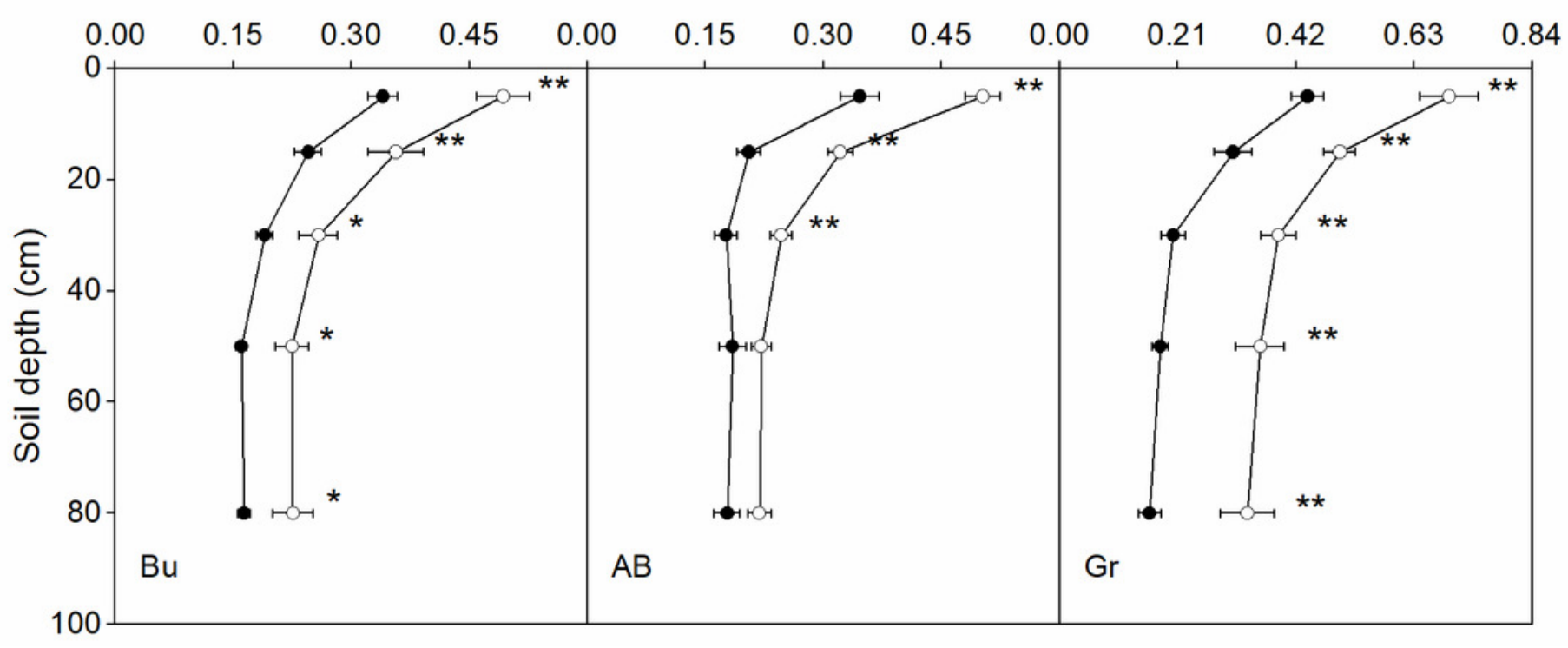


Figure 4

Comparison of SOC and TN stocks $\left(\mathrm{kg} \mathrm{m}^{-2}\right)$ in reclaimed mine sites (RMSs) and undisturbed native sites (UNSs) under different vegetation types (Bu: bushes, AB: arborbush mixtures, and Gr: grasslands).

** and * represent significant differences between RMSs and UNSs at $p<0.01$ and $p<0.05$, respectively. 
(A)

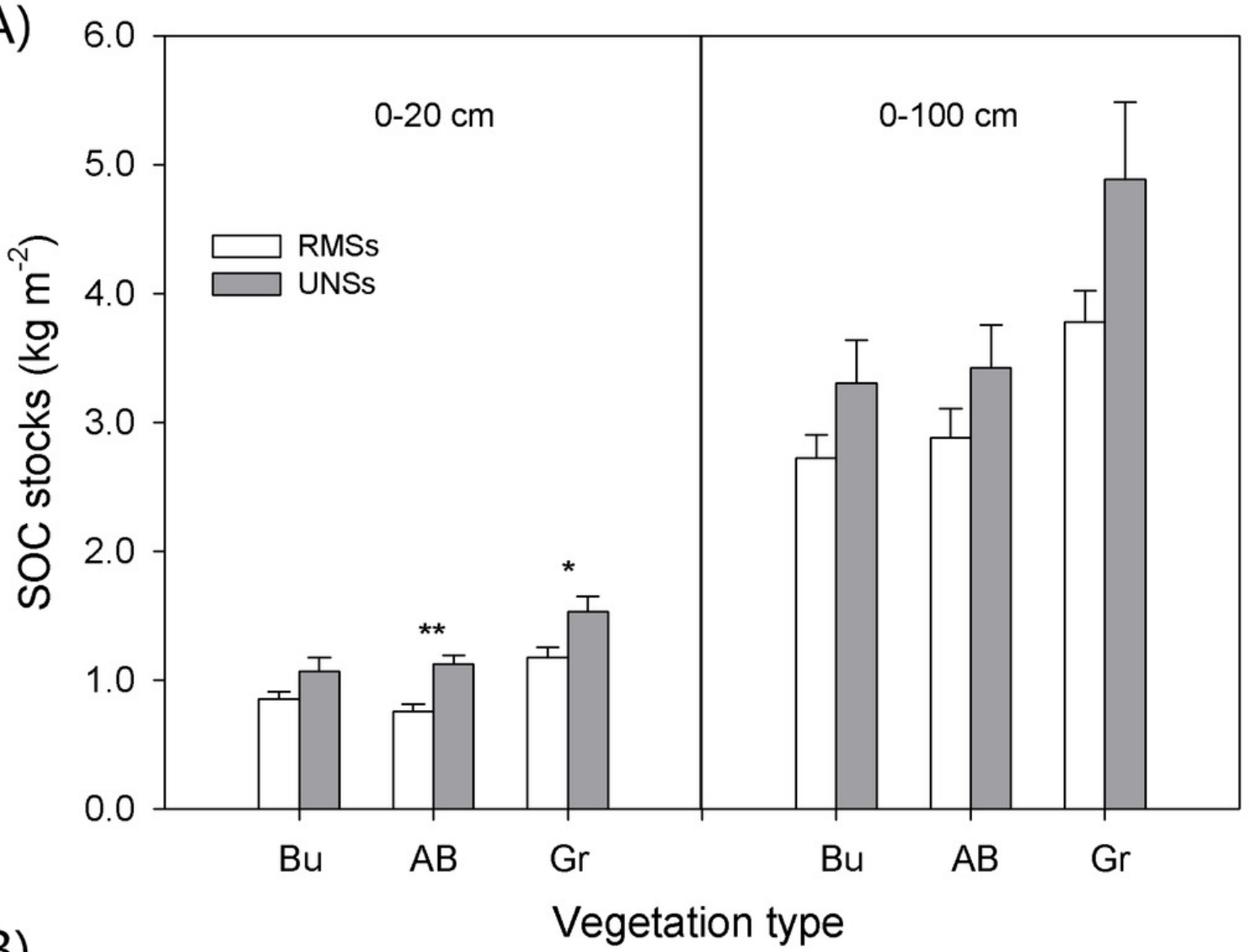

(B)

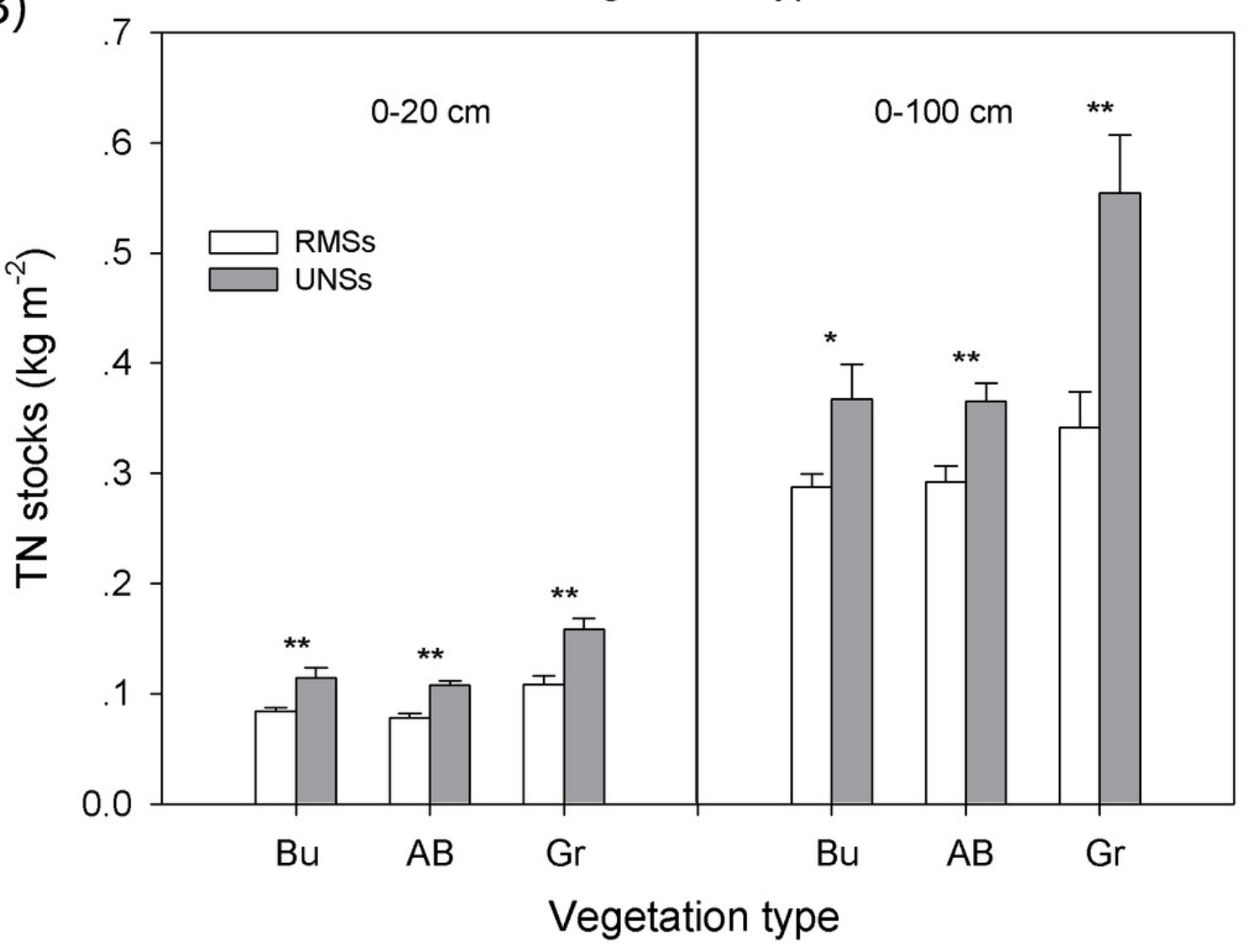


Figure 5

Plant litter in RMSs and UNSs under different vegetation types (Ar: arbors, Bu: bushes, $A B$ : arbor-bush mixtures, Gr: grasslands, and NRS: natural recovery site).

Different lowercase letters represent significant differences between the vegetation types in RMSs and UNSs $(p<0.05)$. Error bars show the standard deviations.

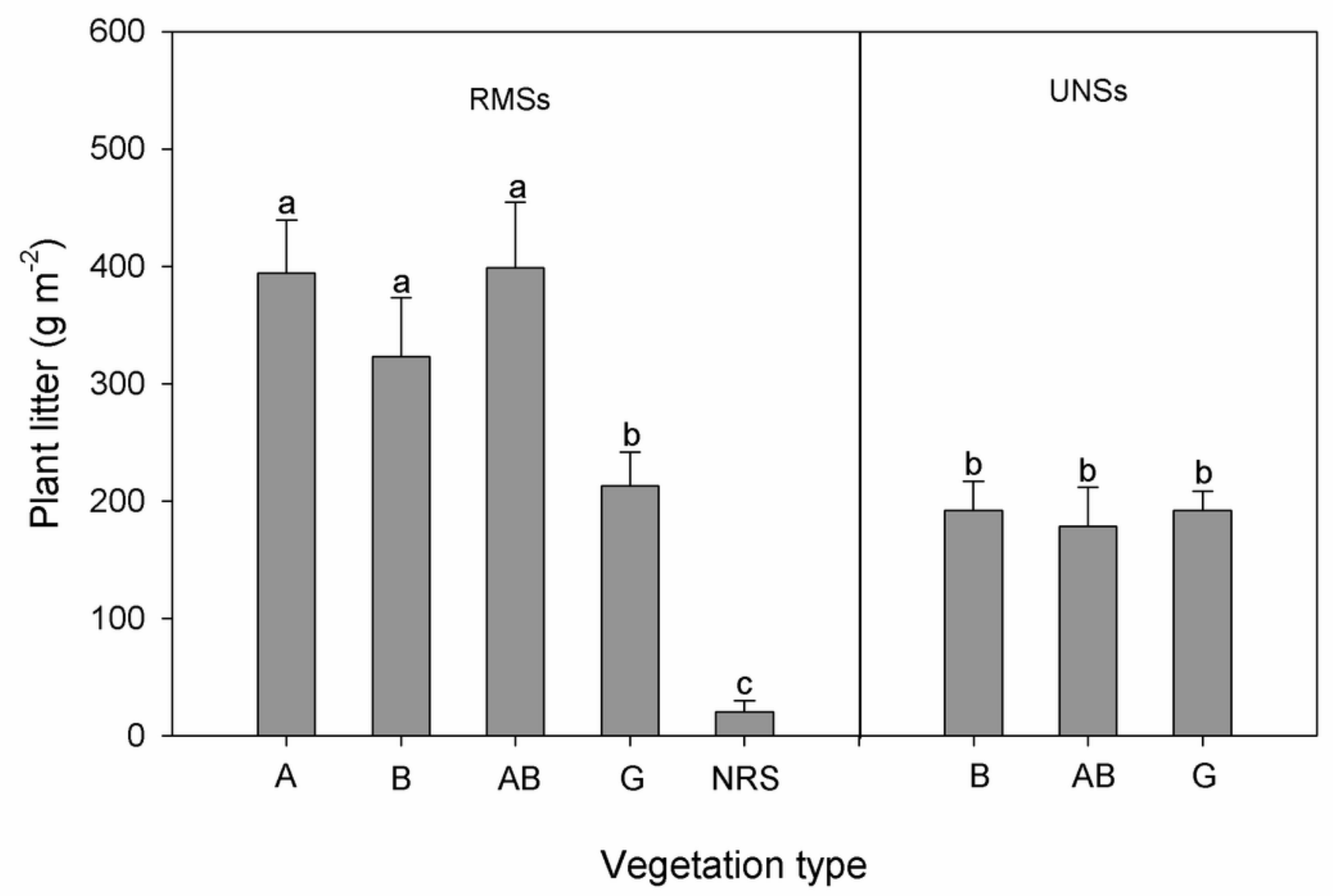




\section{Table $\mathbf{1}$ (on next page)}

Details of the vegetation collocations for the different vegetation types at reclaimed mine sites (RMSs) and undisturbed native sites (UNSs).

Ar, arbors; Bu, bushes; $A B$, arbor-bush mixtures; Gr, grasslands; NRS, natural recovery site;

$H$, height; RS, row spacing; LS, line spacing; D: density. 


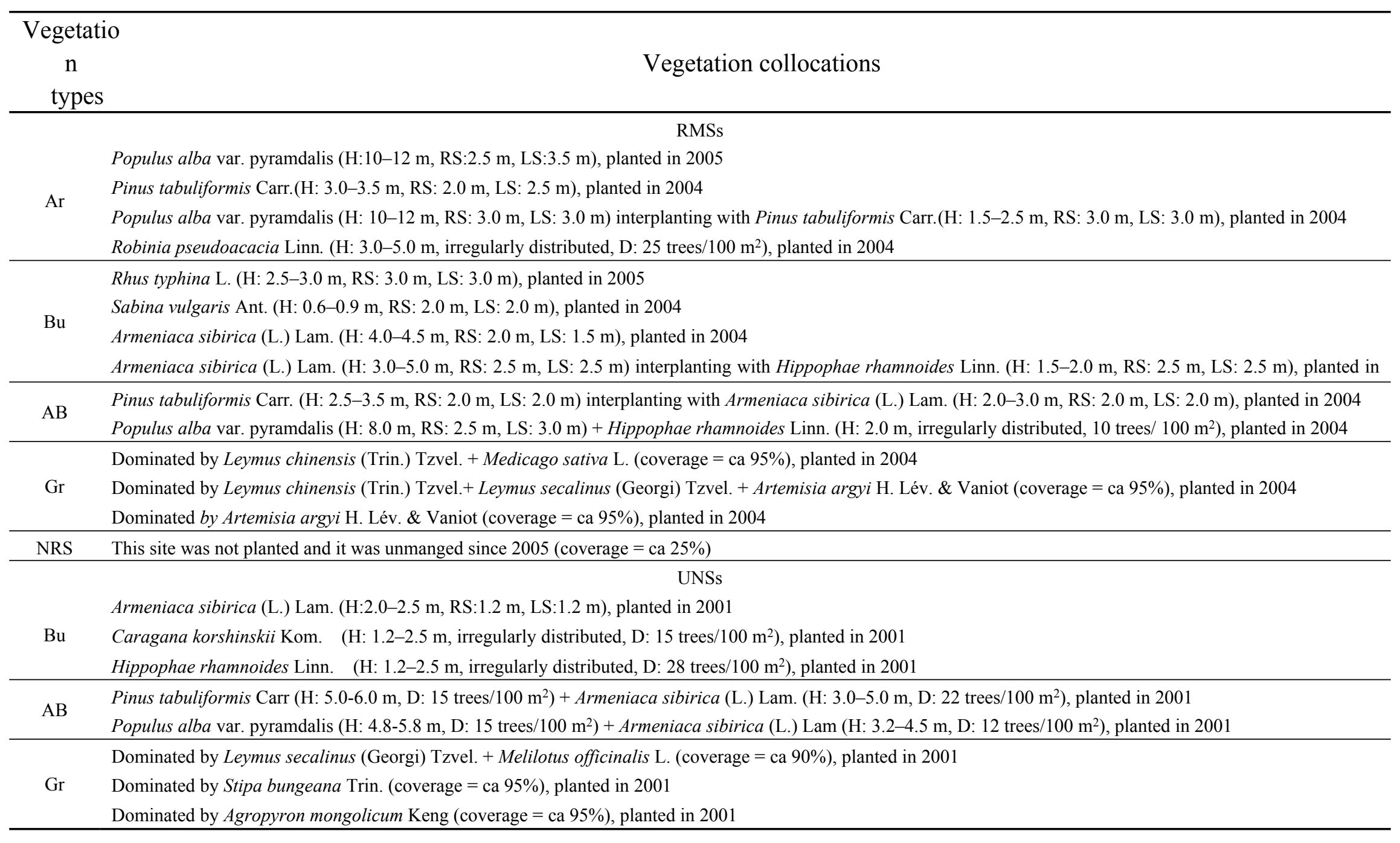




\section{Table 2 (on next page)}

Soil organic carbon (SOC) and total nitrogen (TN) concentration $\left(\mathrm{g} \mathrm{kg}^{-1}\right)$ at different soil depths with different revegetation patterns.

Ar, arbors; Bu, bushes; $A B$, arbor-bush mixtures; Gr, grasslands; NRS, natural recovery site. Values followed by the same lower-case letters in rows and upper-case letters in columns do not differ significantly at $p<0.05$. 


\begin{tabular}{lllllll}
\hline & $\begin{array}{l}\text { Soil depth } \\
(\mathrm{cm})\end{array}$ & $\mathrm{Ar}$ & $\mathrm{Bu}$ & $\mathrm{AB}$ & $\mathrm{Gr}$ & $\mathrm{NRS}$ \\
\hline \multirow{4}{*}{$\mathrm{SOC}$} & $0-10$ & $2.71 \mathrm{cA}$ & $3.68 \mathrm{bA}$ & $3.54 \mathrm{bA}$ & $4.67 \mathrm{aA}$ & $1.90 \mathrm{cA}$ \\
& $10-20$ & $1.52 \mathrm{cB}$ & $2.31 \mathrm{bB}$ & $1.84 \mathrm{bcB}$ & $3.44 \mathrm{aB}$ & $1.45 \mathrm{cB}$ \\
& $20-40$ & $1.22 \mathrm{cB}$ & $1.84 \mathrm{bBC}$ & $1.62 \mathrm{bcB}$ & $2.51 \mathrm{aC}$ & $1.13 \mathrm{cB}$ \\
& $40-60$ & $1.14 \mathrm{bB}$ & $1.34 \mathrm{bC}$ & $1.53 \mathrm{abB}$ & $1.88 \mathrm{aC}$ & $1.14 \mathrm{bB}$ \\
& $60-100$ & $1.14 \mathrm{bB}$ & $1.46 \mathrm{abC}$ & $1.77 \mathrm{aB}$ & $1.79 \mathrm{aC}$ & $1.10 \mathrm{bB}$ \\
\hline \multirow{4}{*}{$\mathrm{TN}$} & $0-10$ & $0.29 \mathrm{bcA}$ & $0.35 \mathrm{bA}$ & $0.34 \mathrm{bA}$ & $0.44 \mathrm{aA}$ & $0.21 \mathrm{cA}$ \\
& $10-20$ & $0.19 \mathrm{cB}$ & $0.25 \mathrm{bB}$ & $0.21 \mathrm{bcB}$ & $0.31 \mathrm{aB}$ & $0.16 \mathrm{cB}$ \\
& $20-40$ & $0.15 \mathrm{bC}$ & $0.19 \mathrm{aC}$ & $0.18 \mathrm{abB}$ & $0.20 \mathrm{aC}$ & $0.14 \mathrm{bB}$ \\
& $40-60$ & $0.14 \mathrm{bC}$ & $0.16 \mathrm{abC}$ & $0.18 \mathrm{aB}$ & $0.18 \mathrm{aC}$ & $0.13 \mathrm{bB}$ \\
& $60-100$ & $0.15 \mathrm{aC}$ & $0.16 \mathrm{aC}$ & $0.17 \mathrm{aB}$ & $0.16 \mathrm{aC}$ & $0.14 \mathrm{aB}$ \\
\hline
\end{tabular}

